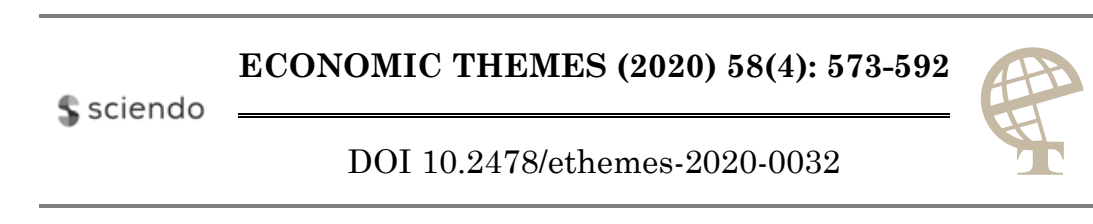

\title{
LEAN ACCOUNTING AND VALUE STREAM COSTING FOR MORE EFFICIENT BUSINESS PROCESSES
}

\author{
Bojana Novićević Čečević \\ University of Niš, Faculty of Economics, Republic of Serbia \\ $\triangle$ bojana.novicevic@eknfak.ni.ac.rs \\ Milica Đorđević \\ University of Niš, Faculty of Economics, Republic of Serbia \\ $\bowtie$ milica.djordjevic@eknfak.ni.ac.rs
}

\begin{abstract}
UDC
657

Abstract: Required customer value, just in time delivery, elimination of all forms of waste from production and all business processes in the company and the like are basic characteristics of lean business concept. Achieving and maintaining competitive advantage, implies to carefully consider and apply the five principles of the Lean concept and establish a

Review value stream. Primarily, the Lean concept was applied in the production paper process, but due to the numerous perceived benefits, the Lean concept can be applied in all company processes, including accounting. Lean accounting involves changing financial reporting, business process control and business decision-making processes. Lean accounting relies on the value stream with all income and expenses. The paper analyzes the application of value stream costing and financial effects of business improvement using the Lean concept.
\end{abstract}

Received: 19.05.2020 Accepted: 29.09.2020

Keywords: Lean concept, Lean accounting, value stream costing

JEL classification: M41

\section{Introduction}

The roots of the Lean concept appeared after World War II, and in the mid-fifties it became widespread throughout the world, after the book "The Machine That Changed the World" was published. Economic and social revival experienced by Japanese industry, led by Toyota and its leading position in car production, and explained by Womack, Jones and Roos in that book. That model was named Lean, 
and allows more results with less use of human resources, equipment, time and space to produce products that meet the needs of picky customers.

The Lean business concept brings added customer value through higher product quality and functionality, shorter product delivery and waiting time. This brings added value to the company itself, in terms of higher value stream profit, low inventories, resource waste and the like.

The Lean concept involves the application of five basic business principles. Defining values is the first principle. End define value. Also to define value mean that demanded product/service best meets customers' needs. The second Lean business principle refers to the establishment of company value streams. The established "value streams" in the company refer to, not only the production, but the entire business process. "Value streams" established in the proper way in the company help eliminate non-value-added activities and waste, reduce defects and downtime, etc. As a place where income and expenses rise at the same time, the value stream is the basis for calculating costs and measuring performance in a Lean company. Establishing "value streams" will ensure removal of all obstacles and the smooth flow of products/services to customers. This is the third Lean business principle. The introduction of pull system is the fourth principle of the Lean business concept. The signal to make a product/provide a service is sent by the end customer, and businesses should strive to maintain an appropriate inventory level to deliver the required value. The last principle of the Lean business concept is the pursuit of perfection. With "value streams" established and running smoothly, the aim is to achieve the best possible company operations as a whole and to constantly search for chances for business improvement.

The Lean company embraces the Lean culture and methods and applies them to all business processes and tasks within the organization. It is an integrated system that effectively creates value for its stakeholders by applying Lean principles and practices. The effects of Lean principles and practices are visible first at the operational level and later at the strategic level. In order to realistically show the benefits of the Lean business principle, the company must modify its accounting process, in terms of data collection and processing, costing, performance measurement and control. This is Lean accounting.

According to the abovementioned, the paper consists of three parts. The first part of the paper points out the vision of Lean accounting. The second part deals with value stream costing, while the third part discusses ways to eliminate unnecessary resource waste and increase the profitability of value stream.

\section{Lean accounting - accounting of the XXI century}

Lean accounting was developed in the mid-1990s to support the management of Lean processes and Lean production. Lean accounting best shows the business 
performance of companies applying Lean production principles. Lean accounting involves collecting and processing data at the value stream level, applying simpler methods to value inventories, and includes non-financial measures to assess performance in addition to financial ones (Brosnahan, 2008). This produces an information system that is at the same time an easy-to-use management and control mechanism, comprehensible to a large number of employees, a system that produces timely and accurate information. The statements resulting from this management and control mechanism do not require much effort to prepare, and are a relevant basis to measure performance, control and make business decisions.

As an information base in the new business conditions, Lean accounting implies primarily the application of Lean principles, tools and techniques in the field of accounting, to speed up the process and eliminate waste, unused capacity, effort and defects (Aghdaei, 2012). The application of the Lean principles in the field of accounting is a logical way to transform a company towards the status of a world-class company.

Long before it became generally accepted, Brian Maskell and his colleagues faced the challenge of creating a new accounting information system for the world's leading computer manufacturing company that hired them as consultants. Maskell and colleagues agreed to create and develop an accounting information system that will (Maskell, 2018):

- Be flexible and timely,

- Be clearly understood by all company employees,

- Bring higher customer value,

- Comply with the requirements of the General Accepted Accounting Principles (GAAP),

- Require rigorous control of financial and operational indicators and

- Allow company managers and CFOs more time for strategic and development activities.

In line with the above, they set a vision of Lean accounting, as shown in Figure 1.

In order to meet the requirements for timely information, Lean accounting statements are compiled on a weekly basis, and more often if necessary, at the level of each value stream in the company. Box Score is used to present information (Novićević Čečević \& Antić, 2016) as a three-dimensional summary of the company performance. The purpose of the Box score is to report on the company's operational and financial performance to make it clear, visible and usable by all employees. This allows employees, when performing their activities, to see how they influence the performance trend of the entire value stream. Furthermore, employees recognize their place and evaluate their role in the business activity of the value stream and the company as a whole and, thus, identify themselves as part of that whole (Novićević \& Antić, 2013). In addition to operational and financial 
indicators, Box Score includes the indicators of capacity utilization that must be considered when making important business decisions. As these three aspects of performance measurement are related, it is clear how to boost sales, maximize customer value and reduce costs significantly. In this sense, Box Score is simple and available when managers need it and, as such, is an effective tool for making business decisions, such as: pricing, producing or buying on foreign markets, accepting special orders, capacity management, etc. (Antić, Stevanović \& Novićević Čečević, 2019) The "Plain English" is especially important when one needs to understand Lean accounting statements. "Plain English" is a general term for communication that emphasizes clarity, conciseness and avoidance of technical terms. Its goal is to communicate in a way that is intelligible to everyone, especially to those for whom it is intended.

Figure 1. Vision of Lean accounting

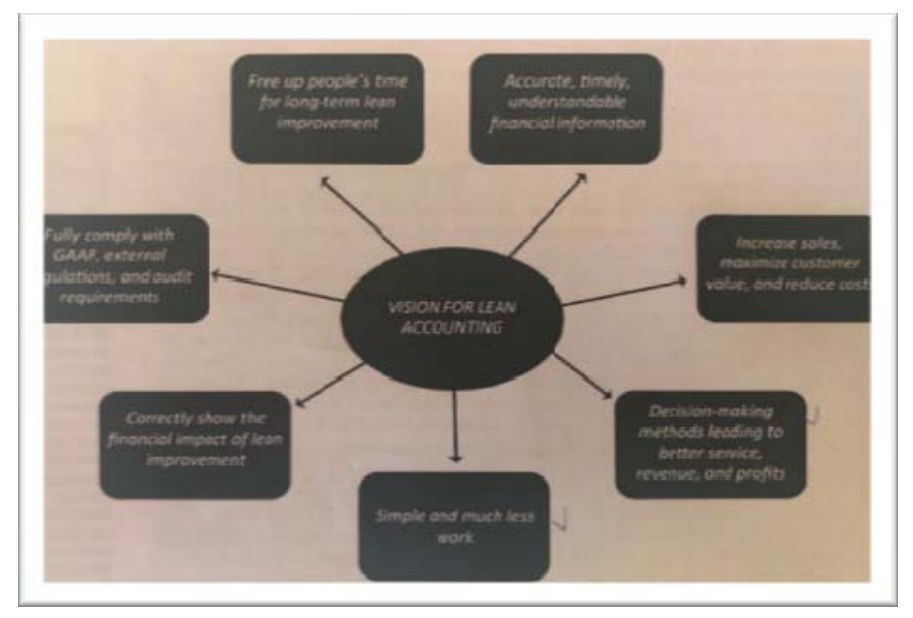

Source: Maskell, B., Baggaley, B., Katko, N., Paino, D. (2007) The Lean Business

Management System, Lean Accounting: principles \& Practices Toolkit. BMA press.

The question accountants and managers often ask is whether the application of inventory valuation method in Lean accounting is in accordance with GAAP and International Financial Reporting Standards. This question is quite reasonable, because the way inventories are valued has an impact on profit. In "value stream" costing, inventories are valued at actual costs, which usually correspond to the period when inventories appeared. According to GAAP, one of the methods for valuing inventories is the average cost method. "Value stream" costing also uses the average cost method to value work-in-progress inventory in the balance sheet and the cost of goods sold in the income statement. The valuation of inventories by applying the "value stream" costing is simpler, easier and more rational (Novićević Cecević, 2016). The rationality of inventory valuation stems primarily from the 
reduced need for detailed monitoring of material costs, because they are very easy to calculate and there is no need to update them until the material is transformed into a finished product. Also, as inventories are capitalized when the business flow is complete, there is no need to monitor labor costs and calculate overhead costs. By valuing inventories through "value stream" costing, it is possible to show the fair value of inventories, i.e. that value that is not burdened by material costs, which is in accordance with GAAP (DeBusk \& DeBusk, 2012). Consequently, inventory valuation by applying "value stream" costing is in line with GAAP, but requires much less work to meet these requirements.

A number of Lean tools makes it possible to look at the entire accounting process and detect both value-added and non-value-added activities. Furthermore, Lean techniques create conditions for the elimination of waste or repetitive activities in the accounting process. In order to eliminate unnecessary accounting activities, Lean accounting seeks answers to the following questions: Who are the users of financial statements? How many documents one really needs to prepare and send for approval? How often are statements used in business? What decisions should be made based on the statements? What key information should the statement contain? Can the verification and authorization system be simplified? How to shorten the lead time (Mcvay, Kennedy \& Fullerton, 2013)? Streamlining the accounting process and eliminating non-value-added transactions and activities simplify and shorten the process of gathering information and compiling statements. By shortening the time employees use in complex and technical processes, more time is gained for substantial changes and improvements. This meets the requirements of the Lean concept in terms of eliminating waste transactions and resources for continuous business improvement.

Human aspect is a particularly important part of the Lean concept, so it is logical that treatment and investment in employees are part of the Lean accounting vision. The Lean concept respects all company employees. It means that all workers, from production process to company managers, are included and have a great importance in the company. All employees are part of a team that continuously strives to improve business activities. Employees' behavior and actions depend primarily on the ingrained business philosophy and culture employees rely on when striving for continuous improvement of the activities they perform. The Lean business concept enables higher employee satisfaction by providing very fast feedback with the aim of turning resource losses and waste into value-added activities.

\section{Value stream costing - the heart of Lean accounting}

In order to apply Lean accounting, the company needs to map "value streams". Value streams generate income, and for realistic presentation of business results, all costs must be allocated to their corresponding value stream. The costing method 
that links all costs to the value stream is called value stream costing. The basic characteristics of value stream costing are (Baggaley \& Maskell, 2003):

- Focused on value stream,

- Simple and easy to use,

- Aimed at measuring value stream performance,

- Focused on elimination, calculation and allocation of overhead costs and

- Clear and intelligible to all company employees.

This costing method does not use detailed data and procedures to calculate costs, but does it at the value stream level at the end of each week. Easiness, simplicity and understandability to most company employees, not just accountants is one of the characteristics of the value stream costing. Traditional costing methods pay a lot of attention to the selection of adequate bases for the allocation of overhead costs to cost objects. The choice of inappropriate keys for allocating the increased mass of overhead costs to cost objects lead to the presentation of distorted information on product costs. Some products are burdened with higher or lower overheads than they actually caused. The situation is somewhat different in value stream costing. All costs in the value stream are considered direct. The information necessary to calculate the value stream profit is collected on a weekly basis, linking all overheads to the value stream as a whole, without the need to use labor hours as the basis for allocation. The costs included in value stream costing are shown in Figure 2.

Figure 2. Costs included in value stream costing

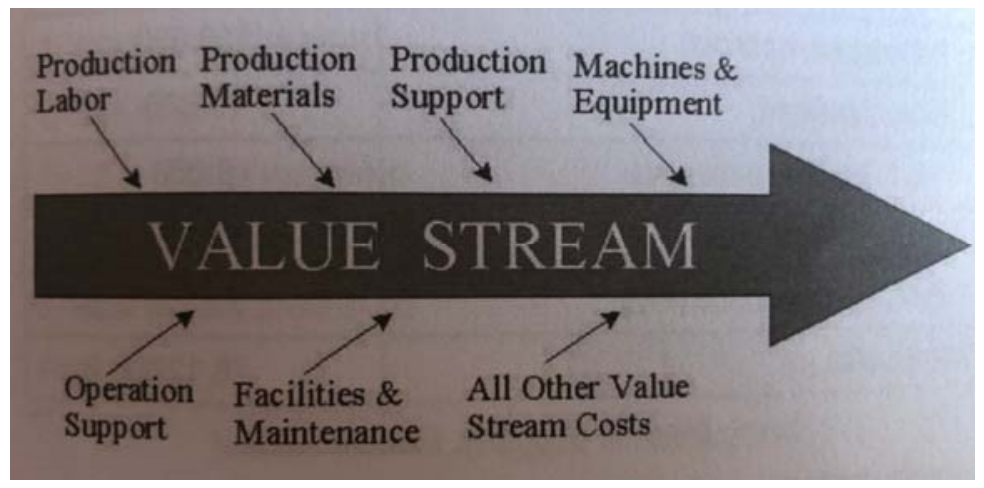

Source: Baggaley, Bruce, Maskell, Brian, (2003) Value stream management for Lean companies, Journal of cost management, May/June, p. 25. Huntzinger, J. (2007). Lean Cost Management, Accounting for Lean by establishing flow. Fort Lauderdale, FL: J.Ross publishing., p. 254.

Labor costs are calculated as the sum of the salaries of all workers involved in the corresponding value stream. The salaries of employees who actively participate in value creation in a specific value stream, but also those engaged in support 
activities (movement of materials, maintenance of machines, etc.) are included in labor costs. Labor costs can be calculated on the basis of the following equation, where labor hours imply a period of one month: (Lopez, Santos et al. 2013)

\section{Labor costs $=\sum$ Salary per unit of time* Time spent at work during the month}

Value stream labor costs include both traditional direct labor costs and traditional indirect labor costs. Data on labor costs comes from the company payroll.

Material costs are obtained on the basis of the amount of material procured for the needs of the value stream during the week multiplied by the purchase prices of the appropriate type of material, and then recalculated on a monthly basis. Each procurement of materials is linked to the value stream. The amount of material procured is equal to the sum of all weekly purchases during the month. Also, the amount of material procured during the month depends on the quantity and value of inventories that exist in the company. The following equation is used to calculate the cost of materials in the observed period:

\section{Material costs $=\sum$ Purchase price of certain types of materials per unit of measure * purchased quantities of certain types of materials}

Production support costs are directly related to the value stream. They refer mainly to costs that traditional costing methods consider indirect. These are maintenance costs, quality costs, salaries of engineers and supervisors, logistics, planning, procurement costs, etc. Direct costing, cost allocation and non-attribution of costs methods can be used to calculate particular value stream support costs (Stenzel, 2007). Direct costing method for value stream support relates to the predicted state of the value stream map. If employees performing production support activities are in the value stream map, then their costs should be directly related to the value stream. A problem can arise if direct costing is too complex. Support cost allocation is only acceptable when the value stream costing is used for the first time. One of the reasons for avoiding cost allocation in this case is that the Lean company functions as a team, so individual employee cost allocation to the value stream can have a discouraging effect on their behavior and jeopardize the entire value creation process. Also, it may happen that the value stream managers, due to the complexity of cost allocation, discuss the levels of allocation at meetings instead of creating opportunities for Lean company advancement.

Machine costs in the value stream include depreciation, spare parts costs and repair costs. The depreciation of machinery is calculated based on the value of individual fixed assets and the corresponding depreciation rates. The problem that arises with companies at the beginning of the Lean transformation process is what to do with write-offs. Accounting regulations prohibit the calculation of depreciation for write-offs. However, from a business point of view, it is advisable 
to use an adequate "replacement value" for the write-off in the form of opportunity costs that can be determined on the basis of the possible market value of these assets.

In the value stream costing, the problem of cost allocation is not pronounced as it was with traditional costing methods. However, when calculating plant costs of a certain value stream, it is necessary to use adequate allocation bases (Maskell, 2016). Plant costs most often refer to the cost of rent or depreciation costs for facilities, plant use or maintenance, utilities and the like. The total plant costs are divided by the square area of the building to obtain the cost per square meter. The plant costs in the value stream are obtained by multiplying the costs per square meter and the number of square meters related to the specific value stream. The number of square meters in a certain value stream includes the square area of the production space, as well as the space for storing resources and employee offices. In this way, only the costs of using a certain area are included in the value stream, without the full allocation of plant costs to the value stream. The allocation of plant costs to the value stream based on the number of square meters motivates managers to reduce the number of square meters in their value stream in order to reduce costs. When reducing the number of squares used in the value stream, care should be taken not to reduce the value delivered to customers (DeBusk \&, DeBusk 2012).

Other costs represent all other resource costs associated with the value stream. These costs are calculated only for the productive time of each workstation, because when the workstation is free or not working then there is no resource consumption (Maskell \& Baggaley, 2003). These costs are calculated as follows:

\section{Other costs $=\sum$ Costs per unit of time * productive time.}

Some Lean company employees cannot be linked to the value stream. The labor costs of these employees are recognized as general and administrative expenses. These costs are not incurred directly in the value stream, but are considered necessary to support the entire operations. The examples of such costs are those related to the following activities: finance, procurement of materials, human resources, engineers, insurance, depreciation of administration equipment and other costs associated with production. Since value stream managers have minimal control over these resource costs, they are not allocated to the value stream, but are reported separately. Presenting these costs outside the value stream costs has a dual purpose (Mcvay, Kennedy et al, 2013). The first relates to the easier visibility of costs non-related to the value stream. Another reason to present these costs outside the value stream is their easy recognition by the value stream teams and reducing the team responsibility to costs under their direct control. These are also the reasons why these costs are specially planned and controlled, and they are reported separately, although their amount is usually relatively small. 
We show value stream costing using the example of a hypothetical company that produces pellet. This company has three value streams: customer order fulfilment (main value stream), vertical positioning and new product development. For the purposes of this paper, we carry out value stream costing in the company's main value stream - order fulfilment. This value stream includes separate workstations: Chips production, Sawdust production, Drying, Pressing and Packing. Due to the volume of work and the large number of tasks to be performed by the workstation, Sawdust production is divided into 4 workstations, as follows: Sawdust production 1, Sawdust production 2, Sawdust production 3 and Sawdust production 4. As these workstations represent the main production operations, we particularly monitor the duration of operations within each workstation and their costs. In addition to production, this company also has Maintenance, Accounting and IT support workstations. The monthly report on the order fulfilment value stream costs is shown in Table 1 (Lopez, Santos et al, 2013).

Table 1. Monthly report on the order fulfilment value stream costs

\begin{tabular}{|c|c|c|c|c|c|}
\hline Value stream & 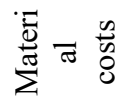 & 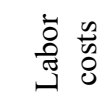 & 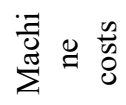 & 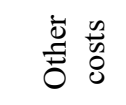 & $\begin{array}{l}\text { त्ञّ } \\
0\end{array}$ \\
\hline Chips production & 3.000 & 2.000 & 1.200 & 444,44 & $6.644,44$ \\
\hline Sawdust production 1 & 6.000 & 2.000 & & 527,78 & $8.527,78$ \\
\hline Sawdust production 2 & & 2.000 & 1.200 & 763.89 & $3.963,89$ \\
\hline Sawdust production 3 & 4.000 & 2.000 & & 1.444 .44 & $7.444,44$ \\
\hline Sawdust production 4 & & 2.000 & & 991.67 & $2.991,67$ \\
\hline Drying & & 2.000 & 1.200 & & 3,200 \\
\hline Pressing & & 2.000 & & & 2.000 \\
\hline Packing & & 2.000 & & & 2.000 \\
\hline Maintenance & & 2.000 & & & 2.000 \\
\hline Accounting & & 8.000 & & & 8.000 \\
\hline IT support & & 8.000 & & & 8.000 \\
\hline Total & 13.000 & 34.000 & 3.600 & $4.172,22$ & $54.772,22$ \\
\hline
\end{tabular}

The amount of material costs for the Chips production workstation is 3,000 m.u. (monetary unit - m.u.), and is obtained by multiplying the monthly volume of production, i.e. company capacity and material costs per unit of product. The monthly capacity of this company is 1,000 units of pellets, and the cost of materials per unit of product for this workstation is 3 m.u. $(1,000$ units of product * 3 m.u. of material costs per unit of product $=3.000 \mathrm{~m}$.u.). The cost of materials for the Sawdust production 1 workstation 1 is 6,000 m.u. and is obtained by multiplying 1,000 units of product with the cost of materials per unit of product, which for this workstation is 6 m.u. The Sawdust production 3 workstation uses material whose cost per unit of product is 4 m.u., which, at a production volume of 1,000 units, gives the cost of materials of 4,000 m.u. 
Monthly labor costs, obtained from the company payroll data for all workers during the order fulfilment value stream amount to 34,000 m.u., and refer to the workers who directly participate in chips production and sawdust production in the amount of 10,000 m.u., 2,000 m.u. in each workstation, 2,000 m.u. on employees in Drying, Pressing, Packing and Maintenance workstations, and 8,000 m.u. for employees in Accounting and IT support workstations.

The machines used in the production process are located in the workstations. One machine is located in the Chips production workstation, the other in the Sawdust production 2 workstation and the third in the Drying workstation, and, accordingly, they are included in the costs of these workstations. Costs per machine - depreciation and maintenance - for a month amount to 1,200 m.u.

Other costs are calculated based on the formula given for other costs. The costs per hour of productive time for the Chips production and Sawdust production 3 workstations are 10 m.u..., while for the Sawdust production 1, Sawdust production 2 and Sawdust production 4 workstations are 5 m.u. To calculate other costs, it is necessary to know the productive time per workstation on a monthly basis. This time is obtained from the value stream map which represents the real state of activities performed in the value stream (Myrelid \& Olhager, 2015) An overview of productive time by workstations is given in Table 2 .

Table 2. Productive time per workstation

\begin{tabular}{|l|c||}
\hline \multicolumn{1}{|c|}{ Workstations } & Productive time (hour) \\
\hline Chips production & 44.44 \\
\hline Sawdust production 1 & 105.56 \\
\hline Sawdust production 2 & 152.78 \\
\hline Sawdust production 3 & 144.44 \\
\hline Sawdust production 4 & 198.33 \\
\hline
\end{tabular}

We get the amount of other costs for the Chips production workstation of 444.44 m.u. by multiplying the productive time in this workstation, which is 44.44 hours, and cost per hour of 10 m.u. and so on for other workstations.

The data obtained in this way on the costs in the order fulfilment value stream is entered in the income statement of this value stream. The income of this value stream amounts to 80,000 m.u., and is obtained by multiplying the monthly volume of production and sales of 1,000 units and the selling price of 80 m.u. per unit of product. In order to make a profit on the value stream, we must deduct the expenses shown in the monthly statement of the value stream costs. Value stream costs in the income statement are presented in two categories: material costs and processing costs. 
In order to obtain the income statement of the company as a whole, it is necessary to show, in addition to the income statement of this value stream, the income statements of the vertical positioning and new product development value streams. We have assumed the income and expenses of these value streams. Summarizing profits by these value streams yields a value stream profit for the company as a whole. The value stream profit obtained in this way is adjusted to take into account salary costs and other costs in general management and administration that are not related to any value stream. As all employees, machines and costs tend to be allocated to one of the value streams, the amount of these costs should be small. A special contribution to the simplicity of Lean income statement comes from the separate presentation of inventories. One of the requirements of the Lean concept is the tendency to minimize inventories, so it is logical to show them separately. Also, this avoids complex inventory calculation procedures, typical of traditional companies. The income statement of value streams and the company as a whole is shown in Table 3.

Table 3. Company's income statement

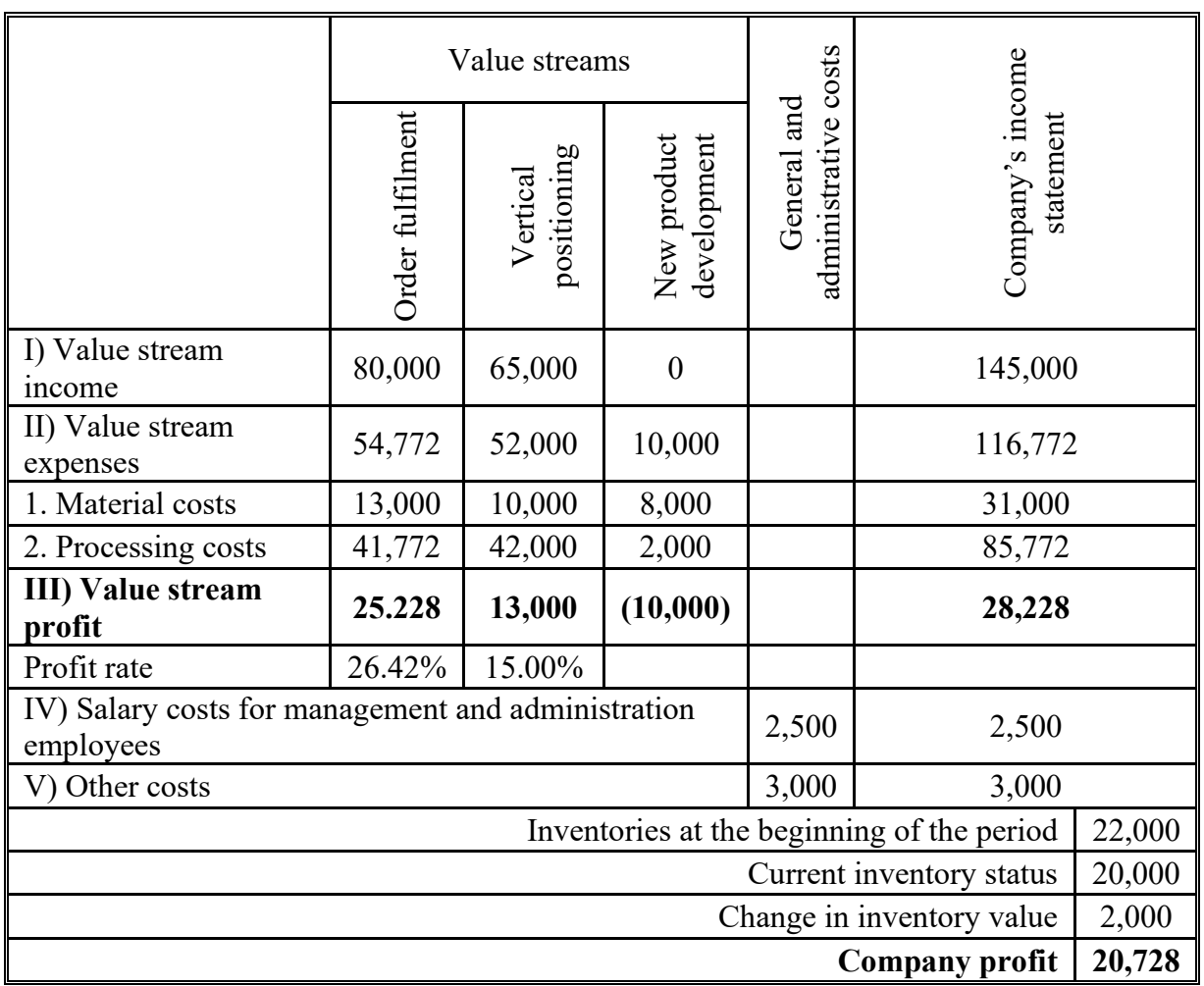


The income statement of the company as a whole contains income and expenses incurred in the company in the observed month and represents an adequate information base for decision-making and management in companies that apply the Lean business concept.

Based on the abovementioned, it is clear that the conceptual basis for calculating the value stream costs is the established value stream in the company. Also, almost all activities, tasks and employees are related to a certain value stream. This ensures an information basis for measuring business success and improvement solely on the basis of the value stream, rather than the product or narrower organizational part performance. Also, it ensures that all resources, machines, employees and processes are linked to the appropriate value stream, which is one of the goals of value stream costing. However, in practice, this is not an easy task.

\section{Elimination of waste to improve business processes}

One of the basic aspirations of the Lean business concept is the elimination of waste, non-value-added activities and all forms of excessive spending in the company. This is because the elimination of waste in value stream is closely related to capacity management. Eliminating unnecessary resource consumption frees up capacities and potential opportunities for streamlining business processes. The free capacities can be used to perform other activities and processes or they can be completely eliminated if technical possibilities allow and if there is no need for their use now or in the future. Eliminating resource waste and alternatively using or eliminating capacity increases value stream profitability.

Using the example of a hypothetical company engaged in the pellet production, whose value stream income and expenses we calculated in the previous part, we show how the elimination of unnecessary resource consumption and the use of freed capacities affect value stream profitability.

The starting point for business improvement is to consider the existing company capacities based on the value stream map (Rother \& Shook, 2003). As the value stream map shows the company's business processes, their duration etc, it is possible to calculate the daily and monthly capacity of this company. We get to the company's daily capacity by dividing the effective working time by the duration of the longest operation in the process. The effective working time in this example is the eight-hour working time of one shift expressed in seconds, i.e. 28,800 seconds ( 8 hours * 60 minutes $* 60$ seconds). The longest operation in the production process is the Sawdust production 4, lasting for 714 seconds. The daily company capacity is 40 units of product $(28,800$ seconds / 714 seconds), and the monthly capacity 1,000 units ( 40 units * 25 working days per month). 
After calculating the daily and monthly capacity, we need to calculate the productive and non-productive time in the process of pellet production, both in total and by individual workstations, depending on the technical and technological characteristics and tasks and operations assigned to individual workstations, using engineering methods.

The results of these methods are information on productive and non-productive capacity utilization, as well as free capacities per production workstations and time of productive and non-productive tasks, waiting times of the first unit and waiting times of the new series, as shown in Table 4.

Table 4. Company capacity utilization - initial state

\begin{tabular}{|c|c|c|c|c|c|c|c|c|c|}
\hline $\begin{array}{l}\text { Working } \\
\text { capacity }\end{array}$ & 䒿 & 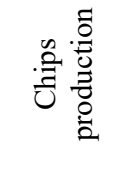 & 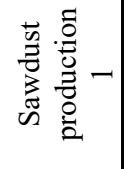 & 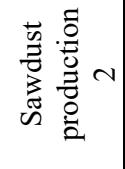 & 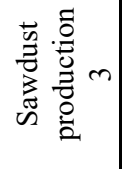 & 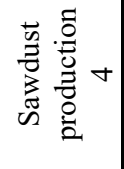 & $\stackrel{\infty}{\stackrel{\infty}{\Xi}}$ & 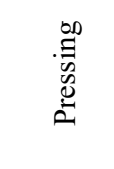 & 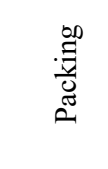 \\
\hline $\begin{array}{l}\text { Productive } \\
\text { time }\end{array}$ & 869,17 & 44,44 & 105,56 & 152,78 & 144,44 & 198,33 & 180,56 & 22,22 & 20,83 \\
\hline & $54,32 \%$ & $22,22 \%$ & $52,78 \%$ & $76.39 \%$ & $72,22 \%$ & $99,17 \%$ & $90,28 \%$ & $11,11 \%$ & $10,42 \%$ \\
\hline $\begin{array}{l}\text { Non-productive } \\
\text { time }\end{array}$ & 368,06 & 6,94 & 0,00 & 0,00 & 0,00 & 0,00 & 13,89 & 175,00 & 172,22 \\
\hline & $23,00 \%$ & $3,47 \%$ & $0,00 \%$ & $0,00 \%$ & $0,00 \%$ & $0,00 \%$ & $6,94 \%$ & $87,50 \%$ & $86,11 \%$ \\
\hline $\begin{array}{l}\text { Free } \\
\text { capacities }\end{array}$ & 362,78 & 148,61 & 94,44 & 47,22 & 55,56 & 1,67 & 5,56 & 2,78 & 6,94 \\
\hline & $22,67 \%$ & $74,31 \%$ & $47,22 \%$ & $23,61 \%$ & $27,78 \%$ & $0,83 \%$ & $2,78 \%$ & $1,39 \%$ & $3,47 \%$ \\
\hline Total & 1.600 & 200 & 200 & 200 & 200 & 200 & 200 & 200 & 200 \\
\hline & $100 \%$ & $100 \%$ & $100 \%$ & $100 \%$ & $100 \%$ & $100 \%$ & $100 \%$ & $100 \%$ & $100 \%$ \\
\hline $\begin{array}{l}\text { Productive } \\
\text { tasks (s) }\end{array}$ & & 160 & 380 & 550 & 520 & 714 & 650 & 80 & 75 \\
\hline $\begin{array}{l}\text { Non-productive } \\
\text { tasks (s) }\end{array}$ & & 25 & 0 & 0 & 0 & 0 & 0 & 0 & 30 \\
\hline $\begin{array}{l}\text { Waiting for the } \\
\text { first unit (s) }\end{array}$ & & 0 & 185 & 565 & 1.115 & 1.635 & 2.349 & 2.999 & 3.079 \\
\hline $\begin{array}{l}\text { Waiting for the } \\
\text { new series (s) }\end{array}$ & & 0 & 0 & 0 & 0 & 0 & 50 & 630 & 590 \\
\hline
\end{tabular}

By reviewing the data on productive and non-productive time, the managers notice that the longest operation in the process is Sawdust production 4, and that it lasts for 714 seconds. This workstation is also a bottleneck in the value stream. By further analysis and application of Lean techniques, managers come to the conclusion that better work organization and faster operations in the Sawdust production 4 workstation shortens the time to perform productive tasks from 714 to 320 seconds. In that sense, they introduce another production line that requires the hiring of one machine and 4 additional workers to perform work within all 
workstations. This reduces the time to perform activities in these workstations by half. Also, they notice a possibility to improve the process of sawdust drying, doing it in two instead of one workstation. The duration of productive tasks in the Drying 1 workstation is 335 seconds in this way, and 305 seconds in the Drying 2 workstation. After such an improvement, the relevant data on capacity utilization is shown in Table 5.

Table 5. Company capacity utilization - the first phase of improvement

\begin{tabular}{|c|c|c|c|c|c|c|c|c|c|c|}
\hline $\begin{array}{l}\text { Working } \\
\text { capacity }\end{array}$ & 吾 & 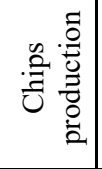 & 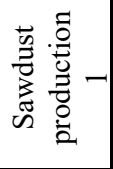 & 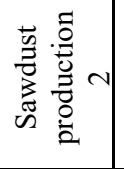 & 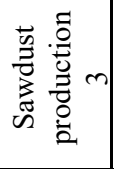 & 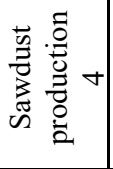 & 它 & 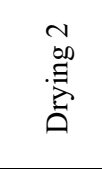 & 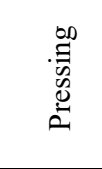 & 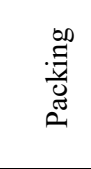 \\
\hline \multirow[t]{2}{*}{ Productive time } & $1.180,56$ & 94,44 & 112,15 & 162,33 & 153,47 & 188,89 & 197,74 & 180,03 & 47,22 & 44,27 \\
\hline & $66 \%$ & $47 \%$ & $56 \%$ & $81 \%$ & $77 \%$ & $94 \%$ & $99 \%$ & $90 \%$ & $24 \%$ & $22 \%$ \\
\hline \multirow[t]{2}{*}{$\begin{array}{l}\text { Non-productive } \\
\text { time } \\
\end{array}$} & 75,78 & 14,76 & 0,00 & 0,00 & 0,00 & 0,00 & 2,00 & & 11,81 & 47,22 \\
\hline & $4 \%$ & $7 \%$ & $0 \%$ & $0 \%$ & $0 \%$ & $0 \%$ & $1 \%$ & & $6 \%$ & $24 \%$ \\
\hline \multirow[t]{2}{*}{ Free capacities } & 543,66 & 90,80 & 87,85 & 37,67 & 46,53 & 11,11 & 0,26 & 19,97 & 140,97 & 108,51 \\
\hline & $30 \%$ & $45 \%$ & $44 \%$ & $19 \%$ & $23 \%$ & $6 \%$ & $0 \%$ & $10 \%$ & $70 \%$ & $54 \%$ \\
\hline \multirow[t]{2}{*}{ Total } & 1.800 & 200 & 200 & 200 & 200 & 200 & 200 & 200 & 200 & 200 \\
\hline & $100 \%$ & $100 \%$ & $100 \%$ & $100 \%$ & $100 \%$ & $100 \%$ & $100 \%$ & & $100 \%$ & $100 \%$ \\
\hline $\begin{array}{l}\text { Productive } \\
\text { tasks (s) }\end{array}$ & & 160 & 190 & 275 & 260 & 320 & 335 & 305 & 80 & 75 \\
\hline $\begin{array}{l}\text { Non-productive } \\
\text { tasks (s) }\end{array}$ & & 25 & 0 & 0 & 0 & 0 & 0 & & 0 & 30 \\
\hline $\begin{array}{l}\text { Waiting for the } \\
\text { first unit (s) }\end{array}$ & & 0 & 185 & 375 & 650 & 910 & 1.230 & & 1.565 & 1.645 \\
\hline $\begin{array}{l}\text { Waiting for the } \\
\text { new series (s) }\end{array}$ & & 0 & 0 & 0 & 0 & 0 & 95 & & 20 & 50 \\
\hline
\end{tabular}

Improvements in the production process increase the total productive time from 869.17 hours to $1,180.56$ hours. This rise in total productive time is a consequence of the rise in productive time in all workstations. Non-productive time decreases by a quarter, while free capacities increase by 178 seconds. The improvements made to the process remove the original bottleneck, and increase production. In that sense, it is necessary to calculate new daily and monthly capacity. A review of data on the use of capacity in the value stream shows that the new longest operation is Drying 1 and that it lasts for 335 seconds. The daily capacity after the improvement is 85 units (28,800 seconds / 335 seconds), and the monthly capacity is 2,125 (85 units * 25 days). It should be noted that the improvements made, in addition to increasing the daily and monthly capacity of the company, make lead time twice as short, and significantly reduce the inventory level held in the company. These improvements are shown through value stream costing, which is presented in Table 6. 
Table 6. Monthly report on order fulfilment value stream costs - after the first phase of improvement

\begin{tabular}{|c|c|c|c|c|c|}
\hline Value stream & 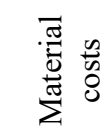 & 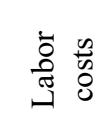 & 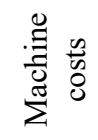 & 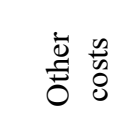 & 氶 \\
\hline Chips production & 6.375 & 2.000 & 1.200 & 944,44 & $10.519,44$ \\
\hline Sawdust production 1 & 12.750 & 4.000 & & 560,76 & $17.310,76$ \\
\hline Sawdust production 2 & & 4.000 & 2.400 & 811,63 & $7.211,63$ \\
\hline Sawdust production 3 & 8.500 & 4.000 & & $3.069,44$ & $15.569,44$ \\
\hline Sawdust production 4 & & 4.000 & & 944,44 & $4.944,44$ \\
\hline Drying 1 & & 2.000 & 1.200 & & 3.200 \\
\hline Drying 2 & & 2.000 & & & 2.000 \\
\hline Pressing & & 2.000 & & & 2.000 \\
\hline Packing & & 2.000 & & & 2.000 \\
\hline Maintenance & & 2.000 & & & 2.000 \\
\hline Accounting & & 8.000 & & & 8.000 \\
\hline IT support & & 8.000 & & & 8.000 \\
\hline Total & 27.625 & 44.000 & 4.800 & $6.330,71$ & $82.755,73$ \\
\hline
\end{tabular}

The total value stream costs now amount to $82,755.71 \mathrm{~m}$.u. It is clearly noticeable that, above all, material costs increase by 14,625 m.u. This rise in material costs is a consequence of the increased production volume from 1,000 units to 2,125 units. Labor costs increase by 10,000 m.u., and the consequence is the hiring of 4 workers (one additional worker for each Sawdust production workstation and 1 worker in the Drying 2 workstation). Due to the introduction of another production line, machine costs in the Sawdust production 2 workstation increase by 1,200 m.u. Other costs increase by almost $2,158.49$ m.u. due to the rise in the volume of production, the increase in the productive performance time, as well as the hiring of additional workers.

Given that the Lean improvement process is continuous and that it involves constant efforts to review and find ways to optimize processes after the first phase of improvement, the second phase follows. The second phase of business improvement in this company goes on to connect workstations. We see that if the Pressing and Packing workstations are merged into one, their total time to perform productive tasks is by 60 seconds lower. Also, their merger eliminates the need to hire one worker, whose costs amount to 2,000 m.u. The time to perform productive tasks in the Drying 1 workstation, which was a bottleneck, drops from 335 to 315 seconds. Despite the fact that the time of performing activities in this workstation is shorter, it is still a bottleneck, but it allows the daily capacity to increase from 85 products to 91 products $(28,800$ seconds / 315 seconds), and it is possible to 
produce on a monthly basis up to 150 products more. The impact of these process improvements on value stream costs is shown in Table 7.

Table 7. Monthly report on order fulfilment value stream costs - after the second phase of improvement

\begin{tabular}{|c|c|c|c|c|c|}
\hline Value stream & 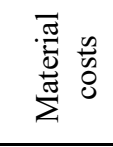 & 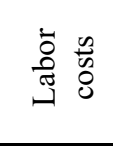 & 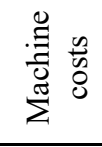 & 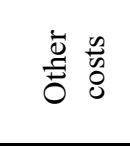 & 吾 \\
\hline Chips production & 6.825 & 2.000 & 1.200 & $1.011,11$ & $11.036,11$ \\
\hline Sawdust production 1 & 13.650 & 4.000 & & $1.200,69$ & $18.850,69$ \\
\hline Sawdust production 2 & & 4.000 & 2.400 & $1.737,85$ & $8.137,85$ \\
\hline Sawdust production 3 & 9.100 & 4.000 & & $1.971,67$ & $15.071,67$ \\
\hline Sawdust production 4 & & 4.000 & & $2.022,22$ & $6.022,22$ \\
\hline Drying 1 & & 2.000 & 1.200 & & 3.200 \\
\hline Drying 2 & & 2.000 & & & 2.000 \\
\hline Pressing and packing & & 2.000 & & & 2.000 \\
\hline Maintenance & & 2.000 & & & 2.000 \\
\hline Accounting & & 8.000 & & & 8.000 \\
\hline IT support & & 8.000 & & & 8.000 \\
\hline Total & 29.575 & 42.000 & 4.800 & $7.943,54$ & $84.318,54$ \\
\hline
\end{tabular}

In relation to the previous value stream costs, the total amount of costs increases from $82,755.73$ m.u. to $84,318.54$ m.u. This rise in costs is primarily a consequence of increased material costs for the production of additional 150 units of product, but also an increase in other costs as a consequence of increased productive time. Labor costs decrease due to the merging of the Pressing and Packing workstations and the need for only one worker to perform these operations.

With the business improvements made through the first and second phases, the monthly production volume increases from the original 1,000 units to as many as 2,275 . The value stream costs grow in proportion to the increase in the volume of production and the engagement of additional resources. However, income generated from the sale of products covers newly incurred costs and doubles the profit rate. An overview of the value stream income, expenses, profit and profit rates through all phases of improvement is shown in Table 8.

Eliminating redundant transactions in value streams requires a detailed activity plan. To make it successful, it is necessary to determine the map of transactions that are performed in the value stream, as well as to determine which Lean techniques and methods can be applied in order to improve business. Through good knowledge of the production process and its weaknesses, while applying Lean techniques, company managers free up capacities used to increase the volume of production. 
Table 8. Value stream income statement

\begin{tabular}{|l|c|c|c||}
\hline \multicolumn{1}{|c|}{ Elements } & Initial state & $\begin{array}{c}\text { First phase of } \\
\text { improvement }\end{array}$ & $\begin{array}{c}\text { Second phase of } \\
\text { improvement }\end{array}$ \\
\hline I) Value stream income & $\mathbf{8 0 . 0 0 0}$ & $\mathbf{1 7 0 . 0 0 0}$ & $\mathbf{1 8 2 . 0 0 0}$ \\
\hline II) Value stream expenses & $\mathbf{5 4 . 7 7 2 , 2 2}$ & $\mathbf{8 2 . 7 5 5 , 7 3}$ & $\mathbf{8 4 . 3 1 8 , 5 4}$ \\
\hline 1. Material costs & 13.000 & 27.625 & 29.575 \\
\hline 2. Processing costs & $41.772,22$ & $55.130,73$ & $54.743,54$ \\
\hline III) Value stream profit & $\mathbf{2 5 . 2 2 7 , 7 8}$ & $\mathbf{8 7 . 2 4 4 , 2 7}$ & $\mathbf{9 7 . 6 8 1 , 4 6}$ \\
\hline Profit rate & $31,53 \%$ & $51,32 \%$ & $53,67 \%$ \\
\hline
\end{tabular}

In the process of improvement, it is important to strive for continuous and gradual elimination of transactions and activities that consume the company resources, and do not add value. When eliminating redundant transactions and activities, there are no strict rules that a company should follow. The elimination procedure depends on the characteristics of the company itself and its business processes. However, the rule that companies should follow is that transactions and activities can be eliminated only when there is no need for those transactions and activities. There is no need to eliminate redundant transactions immediately and without any order, as this can lead to a loss of control over business processes. In such conditions, the company operations become difficult, because the efforts focus on solving the problems caused by the elimination of transactions, rather than on the continuous business improvement and the application of the Lean concept.

\section{Conclusion}

In its initial development stages, the Lean business concept focused only on operational improvements. At this level, the aim was to improve efficiency and reduce costs in the production process by applying certain Lean techniques and tools. The goal was, also to deliver the required value, achieve defined performance, provide a better understanding of the process and facilitate the improvement of business processes and performance by eliminating resource waste and consumption was the goal. By the time, the focus of the Lean business concept expanded from the operational to the strategic level. The aim of this concept, at the strategic level, was to understand the value provided to customers. The value is being considered in terms of product quality, costs, delivery speed, etc.

In order to show the financial effects of Lean improvement, it is necessary to apply a new accounting system that corresponds to the circumstances. This is Lean accounting and value stream costing. The value stream is the conceptual basis of the new costing system. In this sense, the income statement shows only the costs actually incurred in performing the activity in a particular value stream. Eliminating the allocation of overhead costs and linking costs to the value stream enables the presentation of accurate, understandable and relevant information on the value stream operations. 
With the help of Lean accounting and value stream costing, company managers, as well as direct employees, are able to:

- Look at the entire accounting process in the company, as well as the processes that take place within the value stream;

- Identify value-added and non-value-added activities in the accounting process, and then, by applying a number of Lean techniques, eliminate non-value-added activities that are not relevant to the process;

- Make a precise allocation of costs to value streams, with minimal overhead allocation;

- Consider productive and non-productive time, as well as free capacities;

- Identify places where waste and unnecessary consumption occur in the value stream and strive to eliminate them,

- Look at how changes in operational indicators affect the financial results of the value stream;

- Provide an adequate information base for strategic decision-making and measuring continuous improvement and performance.

Well-organized value streams have their own teams, working together to meet customer demands, increasing the created value, value stream performance and company performance on a daily basis. Value stream teams are responsible for both short-term and long-term goals and improvements. To achieve this, value stream team members must think strategically about all the improvements made. In this sense, maximizing the company profitability comes from maximizing the flow of products through the value stream in line with customer needs, rather than from maximizing the use of resources. Product costs depend on how quickly the product goes through the value stream, especially through the production bottleneck, which is the longest operation in the value stream. Also, the amount of costs is affected by the use of resources to create products, as well as the efficiency of employees.

\section{References}

Aghdaei, A. H. (2012). What is Lean Accounting? American Academic \& Research Journal Vol. 4. No.5.

Antić, Lj., Stevanović, T., \& Novićević Čečević, B. (2019). Koncepti obračuna i upravljanja troškovima u Lean poslovnom okruženju. Niš: Ekonomski fakultet Niš.

Bruce, B., Maskell, B. (2003) Value stream management for Lean companies, Journal of cost management, May/June

Baggaley, B., \& Maskell, B. (2003). Value stream management for Lean companies, Part I. Journal of Cost Management (March/April):, 23-27.

Brosnahan, J. (2008). Unleash the Power of Lean Accounting. Journal of Accountancy (July), 60-66.

DeBusk, G. K., \& DeBusk, C. (2012). The case for Lean accounting: Part I. Cost Management (May/June), 20-24. 
Lopez, P., Santos, J., \& Arbos, L. . (2013). Lean manufacturing: costing the value stream. Industrial Management \& Data System Vol. 113 No. 5, 647-668.

Huntzinger, J. 2007. Lean Cost Management, Accounting for Lean by establishing flow. Fort Lauderdale, FL: J.Ross publishing.

Maskell, B. (2006). Solving Standard Cost Problem. Cost Management. Jan/Feb, 27-35.

Maskell, B., Baggaley, B., Katko, N., Paino, D. (2007) The Lean Business Mamagement System, Lean Accounting: Principles \& Practices Toolkit. BMA press

Maskell, B. (2018). Where Lean Accounting Came From and Why? Cost Management, 2834.

Maskell, B., \& Baggaley, B. (2003). Value stream management for Lean companies, part II. Journal of cost management, May/June, 23-30.

Maskell, B., \& Kennedy, F. (2007). Why do we Need Lean Accounting and How Does it work? The Journal of Corporate Accounting \&Finance(March/April), 59-73

Mcvay, G., Kennedy, F., \& Fullerton, R. (2013). Accounting in the Lean Enterprise, Providing Simple, Practical and Decision-Relevant Information. NY: Productivity Press.

Myrelid, A., \& Olhager, J. (2015). Applying modern accounting techniques in complex manufacturing. . Industrial Management \& Data Systems Vol. 115 No. 3. , 402-418.

Novićević Čečević, B. (2016). Upravljačko računovodstvena podrška menadžmentu preduzeća u Lean poslovnom okruženju. Doktorska disertacija.

Novićević Čečević, B., \& Antić, Lj. (2016). Value stream performance measurement and the Lean business concept. Facta Universitatis - series Economics and Organization, 3, 273-286.

Novićević, B., \& Antić, , L. (2013). Upravljačko računovodstvo. Niš: Ekonomski faklutet.

Rother, M., \& Shook, J. (2003). Learning to See. Cambridge: Lena Enterprise Institute.

Stenzel, J. (2007). Lean accounting, best practices for sustainable integration. New Jersey: John Wiley \& Son.

\section{LEAN RAČUNOVODSTVO I OBRAČUN TROŠKOVA TOKA VREDNOSTI U FUNKCIJI UNAPREĐENJA POSLOVNIH PROCESA}

Rezime: Lean koncept karakteriše se obezbeđivanjem zahtevane vrednosti od strane potrošača, brzom isporukom proizvoda, eliminisanjem svih oblika gubitaka kako iz proizvodnog tako i iz svih poslovnih procesa u preduzeću i slično. Da bi se postigla i održala konkurentska prednost uputno je pažljivo razmotriti i primeniti osnovne principe Lean koncepta i uspostaviti tokove vrednosti. Prevashodno se Lean koncept primenjivao u proizvodnom procesu, ali zbog brojnih uočenih koristi Lean koncept se može primeniti u svim procesima $\mathrm{u}$ preduzeću pa $\mathrm{i}$ računovodstvenom. Lean računovodstvo podrazumeva promenu načina finansijskog izveštavanja, kontrole poslovnih procesa i donošenja poslovnih odluka. Baza Lean računovodstva je tok vrednosti u kome nastaju troškovi i generišu se prihodi. U radu se analizira primena obračuna troškova toka vrednosti i finansijski efekti unapređenja poslovanja primenom Lean koncepta.

Ključne reči: Lean koncept, Lean računovodstvo, obračun troškova toka vrednosti 


\section{Authors' biographies}

Bojana Novićević Čečević, PhD, Assistant Professor, was born in 1983 in Niš. She graduated from the Faculty of Economics in Nis and successfully defended her master's thesis in the subject of Strategic Management Accounting. She defended her doctoral dissertation entitled Management and Accounting Support to Company Management in a Lean Business Environment in 2016 at the Faculty of Economics in Nis. Since October 2008, she has been working at the Faculty of Economics in Nis. She is the author of a large number of papers published in leading national journals and proceedings of scientific conferences, co-author of the monograph and workbook from Management Accounting and Cost Accounting.

Milica Đorđević, PhD, Assistant Professor, was born in 1981 in Niš. She graduated from the Faculty of Economics in Nis and successfully defended her master's thesis in 2010. She defended her doctoral dissertation entitled Internal audit in the function of improving corporate governance in 2016 at the Faculty of Economics in Nis. Since 2008 he has been working at the Faculty of Economics in Nis. In 2017, she was elected assistant professor. She is assigned to teach the following subjects: Financial Accounting and Auditing, Accounting Valuation of Financial Instruments and Public Sector Auditing. She is the author and co-author of several papers in scientific and professional journals and is a participant in several scientific conferences and conferences in the country and abroad. 